\title{
Teaching political economy to students of property economics: mission impossible?
}

\section{Franklin Obeng-Odoom}

School of Built Environment, University of Technology Sydney, Australia

Email: Franklin.Obeng-Odoom@uts.edu.au

\begin{abstract}
It is widely held by economists that students of (property) economics self-select to be taught mainstream economics. My experience of teaching a pluralist subject called 'property and political economy' (PPE) has proved to be entirely different. Although some students initially described it as 'irrelevant', major pedagogic revisions have considerably improved students' ratings of the subject. This experience calls into question the view that property economics students are seeking only vocational training to pursue personal wealth. However, it is a mistake to assume that students have an intrinsic desire to study pluralist political economy, even if taught effectively.
\end{abstract}

Keywords: economics pedagogy; property economics; political economy; institutional economics.

Reference to this paper should be made as follows: Obeng-Odoom, F. (xxxx) 'Teaching political economy to students of property economics: mission impossible?', Int. J. Pluralism and Economics Education, Vol. X, No. Y, pp.Xxx-Xxx.

Biographical notes: Franklin Obeng-Odoom works at the University of Technology Sydney where he teaches in the School of Built Environment. He was previously a Teaching Fellow in Political Economy at the Department of Political Economy, University of Sydney. His contribution to pedagogy and higher education has been published in journals such as the Australian Universities' Review and Journal of Higher Education Policy and Management.

\section{Introduction}

Pluralism in the teaching of property economics is rare (Schulte, 2002). According to a general self-selection thesis (Frank et al., 1993, 1996; Frey and Meier, 2003), one would expect that students who study property economics, usually as part of a course in real estate, self-select to be taught mainstream economics. This self-selection, the argument goes, justifies the continuation of business-as-usual (Frey and Meier, 2003) and, by implication, the non-inclusion of pluralism in property economics courses [Obeng-Odoom, (2016), pp.1-12]. Survey results (e.g., Weinstein and Worzala, 2008; Jayantha and Chiang, 2012) of where real estate economics graduates aspire to work, what they do at the workplace, and what they prefer to be taught seem to confirm this conclusion. A narrow curriculum matches narrow course expectations and career aspirations. Samuelson's (1938) 'revealed preference' theory, inferring what people want 
from what they actually buy, suggests that this selection is their free choice without probing the social provisioning of choices.

Recent work by social economists, however, calls the self-selection thesis into question, suggesting that there are elements of conditioning and systematic indoctrination. Institutional set-up, the choice of speakers at events to attract property economics students, the choice of readings, and the mix of real estate economics faculty exemplify various ways students can be conditioned [Obeng-Odoom, (2016), pp.1-12]. One may infer that, if property economics students were exposed to pluralist education, they might find it engaging and could potentially embrace it. Verifying these claims, however, is difficult because it is rare to find a pluralist subject within a property economics course or degree program.

My own experience in using a pluralist approach to teaching property and political economy (PPE) (a political economy subject with the code 16232) at the University of Technology Sydney (UTS) in Australia, therefore, warrants careful study. Why was the subject developed? What educational philosophies guide the subject? Which pedagogical practices have been used? How have students responded?

To answer these questions, this paper draws on official subject outlines, various assessment packs and task sheets, the undergraduate courses guide (Faculty of Design, Architecture and Building [DAB], 2017), and several university-administered student surveys (UTS, 2010, 2011, 2012, 2013a, 2014, 2016). The paper also utilises informal student and peer feedback obtained at various events. These data are complemented by student-administered questionnaires; feedback from the UTS graduate certificate in higher education course teachers; suggestions by other teachers and peers on the property economics course; and feedback from peers and mentors in other departments and schools.

I show that, although it is widely held by economists that students of (property) economics self-select to be taught mainstream economics, my experience suggests that a pluralist approach can be acceptable, effective and engaging for students. Although often described as 'irrelevant', major pedagogic revisions have considerably improved students' ratings of the subject. This experience calls into question the view that property economics students are pre-committed to mundane vocational training to pursue personal wealth. However, it is a mistake to assume that students have an intrinsic desire to study pluralist political economy, even if well taught.

The rest of the paper is divided into four sections. The first provides the subject background and why we developed it in a pluralist manner. The second explains the underlying educational philosophies, while the third details the pedagogical practices and how they evolved. The fourth analyses the effectiveness of the teaching and learning practices.

\section{Historical context}

PPE commenced in the mid-1990s as 'land studies'. It was first offered following a landmark ruling which established the principle (known as the 'Mabo case') that the indigenous people of Australia were the true and original custodians of Australian land in Australia. This verdict created a greater awareness of land rights, and a general feeling among the members of staff that the majority white population of Australian society had very limited understanding of communitarian land tenure systems. The immediate 
concern was to shed light on communal property in Australia and its relationship with land tenure systems more familiar to the Australian population.

The course also aimed to address three bigger issues: to demonstrate the links between social problems and property relations; to show that the dominant, Western property system is not necessarily the best solution to social problems; and to analyse the vast range of alternatives to the dominant system (Small, 2001). As property economics as a field of study was also lacking a coherent analytical methodology (for discussion, see Boydell, 2007), the new unit of study was also "intended to strengthen the academic depth of the property economics course by teaching the history, philosophy, and anthropology of property rights ${ }^{1, ”}$.

Within this broad framework, the particular emphases of various teachers differed. At the beginning, greater emphasis was given to how different cultures understand property rights as well as various philosophies of property. Over the longer-term, however, there was pressure to make the subject more 'industry relevant' ${ }^{2}$. Indeed, the most common criticism of the subject was that its content had no relevance to students' work experiences and hence was of no immediate use to the job of a property economist. Other criticisms were that the subject was too advanced, required too much work, or used too many international examples. The university academic administrators and administrative academics asked the subject's teachers over the years to answer queries about why the subject was poorly rated.

In 2014, as a new lecturer for this subject, I assumed full responsibility for its design and delivery. Although I had previously contributed a couple of lectures per year to the subject, the challenge of taking overall responsibility for its redesign brought new possibilities, but also uncertainties and challenges.

\section{Educational philosophy}

A starting point was the recognition that the field of property economics had originated in the work of early US institutional economics. I analysed the work of R.T. Ely, J.R. Commons, and Thorsten Veblen for inspiration. Ely's official appointment as 'professor of political economy'; his books on property such as Property and Contract in their Relations to The Distribution of Wealth (Ely, 1914); which have become the bedrock of PPE in the original institutional tradition; and the name of the field he pioneered (land economics), implied that the study of 'property economics' and 'land economics' should be seen as 'PPE'. So, I redesigned the subject around two critical features: providing a direct challenge to mainstream neoclassical economics (as original institutional economics had done); and developing a distinctive political economy approach to addressing social problems and providing alternatives for a better society, economy, and environment. Ely (1938/2011) called this approach 'look and see'.

This approach encourages property economists to combine practical knowledge with book knowledge, recognising that theory without practice is comatose and practice without reflection on its underlying theory is problematic. According to Ely (1938/2011, pp.186-187): "a man [sic] of knowledge, who habitually fears to take an active part in the work of life, is himself a wretched being and a useless member of society"; and, quoting his student J.R. Commons, he pointed to the other extreme: "experience without brains". The look and see approach, however, was the common theme for economists who 
opposed crude deductivism and embraced, instead, evolutionary inductivism which combined deductivism with actual experience (Ely, 1938/2011). These institutional economists were also political economists.

I decided to draw on a wider range of perspectives on land economics - beyond institutional economics, however, including Georgist economics, Marxist economics, ecological, feminist, and stratification/postcolonial economics.

To accompany these pluralist changes, I adopted a new, consistent teaching philosophy based less on disseminating professional and technical experience and more on dialogue. A dialogical philosophy draws on student experiences in an ongoing dialogue between the students and the teacher (Freire, 1970). Unlike teaching philosophies based on the 'banking model' of education for which students are considered empty bank accounts, with the teacher solely making deposits, I make it a key part of my teaching to recognise that ideas have materialist foundations and are continuously contested.

Thus, theories need must be seen in the context of competing interests, related to the class structure in society. Ideas that legitimise the position of the powerful more easily flourish than those questioning the status quo. It is because of this dynamic that, in spite of recurrent economic crises arising from the implementation of mainstream economics, the core curriculum of mainstream economics has maintained its continuity and dominance (Thornton, 2014, 2015, 2017). In turn, students, with specific material conditions need to share their experiences and reflect on them in the same way that I share my experiences and invite students to consider the experiences of others (Freire, 1970). In this way, I recognise the limits of my own knowledge and open up for contributions by students. My philosophy, then, is to teach how to think.

\subsection{Pedagogical practices}

One key pedagogical challenge in my three-hour weekly meetings with students is to keep them sufficiently interested for this long period of time. My approach has been to give a one hour lecture, dialogue with the students over two readings (one mainstream; the other political economy) during the second hour, and then invite the students to dialogue with each other in a debate on a controversial topic around property (e.g., mining, social, and ecological tensions) in the third hour. The aim is to create enthusiasm among students and actively encourage them to question existing social relations influencing how property is interpreted.

I have taken a number of interrelated steps to further develop these pedagogical practices. First, I have actively sought the advice of leading political economy teachers and the previous teachers of the subject as well as colleagues in the School of Built Environment; and actively sought feedback from past and current students. Among those consulted is Australia's leading teacher of political economy, Frank Stilwell - described by Thornton (2014, p.113) as "a true pioneer of pluralist economics teaching". I have observed Stilwell's teaching practice by attending some of his lectures and watching others on vimeo (https://vimeo.com/24159128). I have noted his strategies, and discussed them with him - usually over lunch - encouraging reflection on why he did what. I have also met past students of the course to seek their feedback on subject outline sent to them prior to meeting, and asked them to offer suggestions on how to make the subject work better for students. Out of such meetings, I have been persuaded to use Youtube videos of TED Talks, for example, to enliven my classes. 
I have also come to realise that, in the dialogical approach to teaching, it is important to know students personally. So, open information and orientation days provide an important opportunity to learn more about students in contrast with the practice of mainstream property economics teachers who attend such days apparently to ingrain capitalist property behaviours in prospective or new students. For instance, at the University of Sunshine Coast in Australia, one lecturer is explicit about how he uses his attendance to get prospective students to "play serious property games" that is, to "buy, hold and sell Sunshine Coast property to get rich” [Boyd, (2016), p.36]. According to this view, encouraging aggressive competitive behaviour and property investment is the best way to learn about property. In his own words: "in playing property, ruthlessness in game play is encouraged through player-to-player communication where students are free to assist or mislead their peers" [Boyd, (2016), p.36]. These 'property games' show how prospective property economics students may be indoctrinated to be materialistic, individualistic, and utility-maximising, consistent with the findings of Frank et al. (1993, 1996) and Frey and Meier (2003).

Following the established pluralist education tradition in political economy (see, for instance, Butler et al., 2009; Stilwell, 2011), I set out, instead, to broaden the world views of prospective students when I attend such events. I seek to understand why students come to study property economics. Doing so helps me better design my subject to pay attention to students' experiences. Between 2016 and 2017, I asked students who visited the property economics desk during open days at the university where I teach, the questions in Table 1.

As students visit the desk mainly to seek information and are often in a hurry to check out other courses, I only had 19 respondents. Their responses, nevertheless, are revealing. Of the total, only five persons wanted to become property developers; three considered becoming property developers but were unsure; and the remaining respondents did not know what career paths to follow: they simply wanted to try out the property economics course. Of the 19 respondents, twelve obtained course information from their family members; the rest obtained information from elsewhere such as teachers and the Universities Admissions Centre (UAC). Regardless of their information sources, most of the respondents (16) wanted to take the course to enhance their chances of getting a job, although the remaining three highlighted that they simply wanted to take the course for 'intellectual reasons'. A small majority of the students had relatives who worked in the property industry.

These findings are consistent with my own observations and those of colleagues with whom I attend information and orientation days. Some potential students are accompanied by parents urging them to take property economics. Many such parents are already working in the property industry themselves. In most cases, however, parents are also curious to know what the course is about. Often, many prospective students and their parents like the 'economics' label of the course, but are wary that abstract theorisation or mathematics/econometrics would neither be enjoyable nor enhance post-graduation employment. 
Table 1 Property economics open day questions for prospective students in property economics

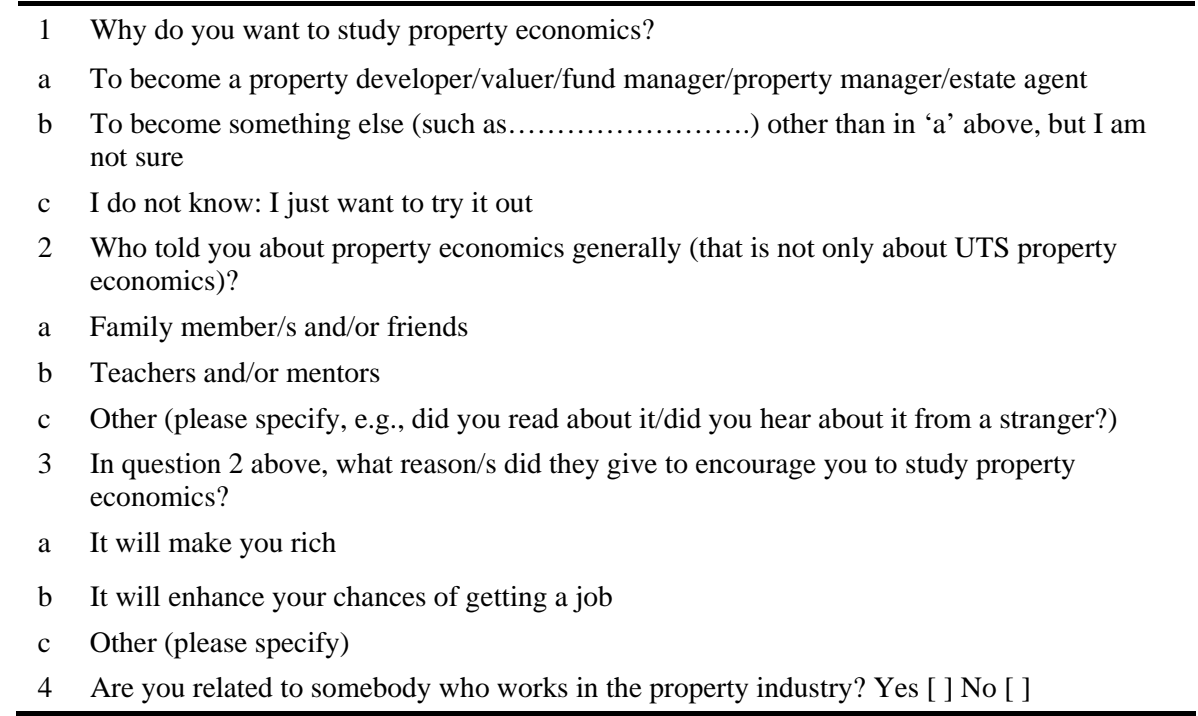

Source: Author, 2016, 2017

These results and observations at open and information days have shaped how I engage with students. For prospective students, I try to first highlight what is in the program brochure:

"If you've thought about a career in business, economics or property, the Bachelor of Property Economics will provide the edge you need to get started in a global industry. In this degree you will learn the specialist knowledge required to enter the property sector, with skills in property valuation, market analysis, investment and development. ... There are many opportunities for graduates: you may work for a property developer, funds manager or real estate advisory firm. Notable positions include working as a property valuer, asset manager, market analyst or finance specialist. Others include sales and acquisitions, property researcher and corporate real estate advisory roles. These positions are the foundation for more strategic roles, including funds and development manager careers [Faculty of Design, Architecture and Building (DAB), (2017), p.33].

Next, I draw the attention to opportunities in the public and nongovernmental sectors. Property economists might also work for governments or in the public sector agencies dealing with urban planning or the provision of housing. I highlight that the skills of property economists could be in useful demand in non-governmental organisations, especially those concerned with affordable housing.

Then, I explain the wider reach of property economics. I highlight that property economists also study the property basis of the economy, the property basis of social problems; and hence the course seeks to develop a property economics approach to addressing social problems and changing existing social relations. I try to dialogue with 'students on the need to develop skills such as the ability to analyse the institutional and social basis of the economy-society-environment milieu, being able to show the role of land in political economic processes and developing the skills to analyse the role of 
institutions such as property in global sustainability, prosperity, and social justice. Topics include the role of the propertied class and problematic property relations in economic crisis, famine, and migration, continuing global inequalities and poverty, discrimination, gentrification, and racism.

Exposure to such issues could be useful background for positions with the Food and Agricultural Organisation, the United Nations Research Institute for Social Development, United Nations Human Settlement Programme, United Nations Environmental Programme, the Asian Development Bank, and the African Development Bank. Locally, positions in the public service, local government, and regulatory agencies of the public sector are all possibilities for property economists as are independent economic consultants, advocates, and activists in think tanks and other non-governmental organisations. I also highlight the possibility to become political economy teachers and researchers - not just property market analysts for corporate interests.

This emphasis prepares the ground for when students are enrolled. I present the subject as developing four fundamental themes in property economics, namely: core concepts, theories, and approaches in property rights debates; property, the extractive industries, and society; political economy of Indigenous property rights; and property and the green economy. I clarify that the subject is global in orientation, but draws on examples and experiences from Australia and the Asia-Pacific region. I teach a wider range of economic viewpoints (such as Georgist land economics, Marxist economics, and institutional economics); rather than conventional real estate economics based on neoclassical ideas. I make the case for pluralism as the most effective antidote to both intellectual and political bias and as a compass for exploring alternatives for a better world (see, Stilwell, 2005, 2006, 2011, 2012).

Because pedagogical practices usually work better if they are articulated within students' experiences, I have tried to make it a point to learn students' names and try to get a sense of their interests and aspirations. Outside lectures, I have tried to create opportunities to meet students one-on-one; for example, through creating study groups that can meet me outside class hours. I have also tried to ensure good quality communications that foster dialogue.

More formally, I have undergone a structured teacher training course, including a series of sessions on course design and assessment (010043). During this program, my PPE subject outline was evaluated for 'constructive alignment' (Biggs and Tang, 2011). Based on that exercise, it was commended in some aspects, but criticism, notably by the course coordinator and my reflections, indicated that it required an overhaul in three respects. First, its aims were too many and how they were to be achieved in teaching and assessments were unclear. Second, how the subject promised to develop the required UTS graduate attributes was not always effective. Third, the description of the subject did not sufficiently convey to students:

a what the subject does, how and when

b what specific skills and attributes are developed in the subject and in what ways

c how the subject is assessed to achieve its intended aims consistent with its own spirit.

In short, the subject was lacking in constructive alignment.

Setting out to reconstruct the subject based on this feedback, I reduced the subject aims, making them more succinct and more strongly centred on the subject's core 
strength: critical thinking, writing, presentation and research in property economics. I also overhauled the description of the subject, revised the assignments, and their weighting.

In addition, and based on previous student feedback, I became more selective in my choice of recommended readings, relying on the most engaging, succinct, and relevant articles. I strengthened the focus of the Asia-Pacific region and on the advanced capitalist countries, especially Australia with which even international students were familiar. My suggested readings became typically shorter than previously, although those with strong student endorsement remained in the revised outline.

To ascertain the adequacy of my revisions, I took three further steps. First, I asked the coordinator of the course design and assessment course for feedback. Second, I asked for some feedback from previous teachers and others specialising in the broader area of the subject. Third, I shared my draft with former students of the subject for comments and fortunately received feedback from five of seven. While this feedback confirmed the view that the subject had transformed, it also generated additional suggestions that I incorporated in the subject.

\section{Educational outcomes}

Judging the effectiveness of teaching is seldom simple, especially because outcomes tend to be contingent on both personal and external factors. The principal means are university administered online questionnaires and focus groups run by external marketing firms or internal marketing departments. While these approaches have their place, they have limitations as the sole basis for judging the effectiveness of teaching and learning. Their impersonal character removes the teacher from the assessment process and gives equal weight to the assessment of students who may never have attended any classes at all but can have access to a computer to complete online surveys. Standard student feedback surveys (SFS) can also be biased against pluralist courses because they do not probe the complexities that define pluralist pedagogies. Such surveys also tend to encourage easy grading (Schneider, 2013).

What are the alternatives? One is to redesign SFS to focus on seeking feedback on whether the students' views have been challenged in fundamental ways. Another is to seek peer review of teaching material and/or teaching practices (Schneider, 2013). A third is to use a variety of data, including student-centred and administered questionnaires, self-reflection by students, and observations by teachers (Stilwell, 2011, 2012). What makes this last option preferable is the advantage of triangulating the teaching and learning experience from different perspectives, which is consistent with a pluralist pedagogy.

\subsection{Self-reflection and peer review}

Ultimately, of course, the teacher determines what changes to make in the light of feedback and critical reflections. In reflecting on the changes I have made to PPE since 2014 and seeking to self-evaluate, I draw on the idea of 'constructive alignment' (Biggs and Tang, 2011) which identifies three iterative tests to be applied, the outcomes of which determine further steps (e.g., type of feedback) to be taken to enhance alignment (Boud and Falchikov, 2007; Biggs and Tang, 2011). First, do the assessment tasks test 
whether the learning objective has been achieved? Second, what intermediate steps (learning activities and intermediate feedback/feedforward) have been taken and reinforced between positing the learning objectives and carrying out the assessment? Third, do these intermediate steps orient and reinforce the contribution to successfully completing the assessment tasks and hence the learning objectives? As curriculum (re)design is an ongoing process, my intention is not to claim victory/failure but to continue with my self-evaluation to be complemented with future student responses. The three interlocking assessment tasks used in the subject are diagrammatically represented in Figure 1. These tasks also seek to develop five graduate attributes, namely: communication and group work (C); attitudes and values (A); practical and professional $(\mathrm{P})$; research and critique (R); and innovation and creativity (I); CAPRI, for short.

Figure 1 Assessment tasks, PPE (see online version for colours)

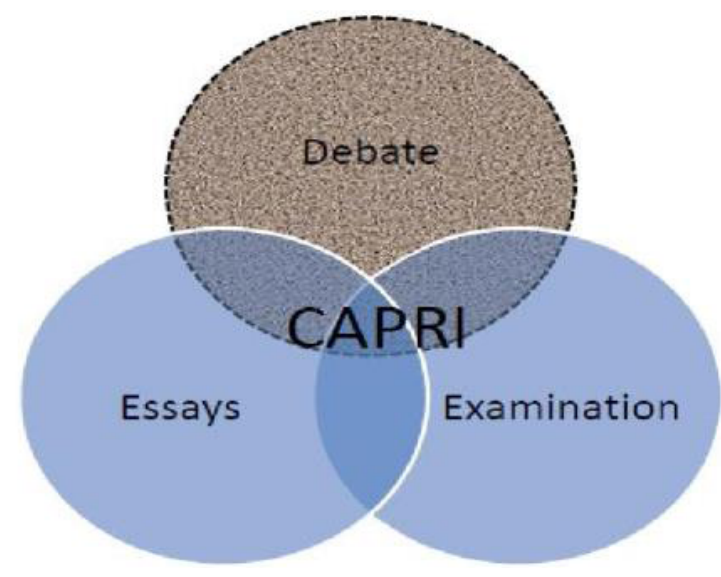

Source: Author

As shown in Figure 1, the assessment tasks for my PPE subject entail debates, essays, and examination helping to develop CAPRI in various ways. The first assessment task is a 1,500 word critical review of one of the student readings (which highlight, summarise, clarify, and extend key controversies in the debates/tutorials, and readings). The assessment task is intended to achieve the third aim of the subject: "critically analyse existing property-based proposals for reform grounded in careful reasoning and systematic research”.

The second assessment is in two parts. The first part is a debate and the second, class participation (involving contribution to class discussion of set readings, answering tutorial questions, judging peers in a debate and submitting both oral and written statement of the verdict, and time-keeping during a debate). This second assessment is intended to achieve the first two aims of the subject:

1 comprehend and be able to explain the property basis of global social problems

2 evaluate the strengths and weaknesses of contested perspectives on property and social problems, while presenting convincing and reasoned arguments to a variety of audiences. 
The third assessment task is an examination to test the fourth aim of the subject: "apply the skills developed in PPE to real world problems in conditions under which property economists work".

These assessments are not only internally interlocking but also externally integrated. As shown in Figure 2, the learning objectives drive the learning activities which, in turn, feed in to the assessment tasks.

Figure 2 Alignment between the current assessment tasks, the learning activities and learning objectives in PPE (see online version for colours)

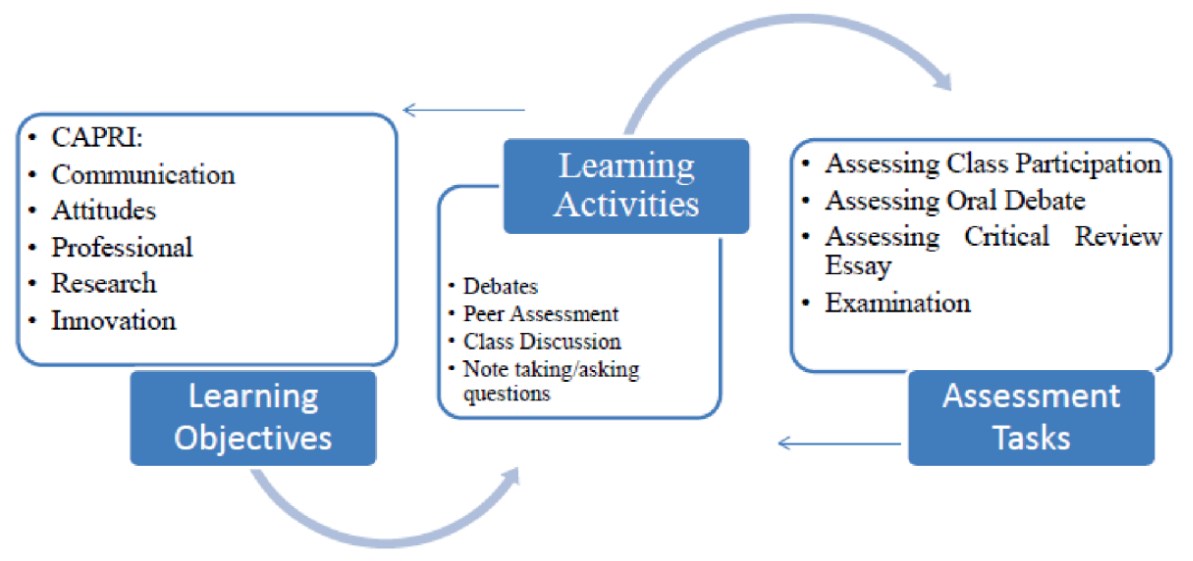

Source: Author

There is a strong alignment within the assessment tasks and between the current assessment tasks on the one hand and the learning activities and objectives on the other. The assessment tasks have been designed so that completing one prepares the students for the next task. Aside from this internal coherence (Figure 1), the assessment tasks also align well with the learning objectives/graduate attributes. Thus, tasks reinforce one another in seeking to achieve agreed learning objectives.

I use feedback throughout the semester to help to keep the various parts of the subject aligned. The nature of the feedback ranges from feed forward (feedback given on draft essays/answers to questions about essays before they are due) to feedback (summative and formative written feedback ranging from half to one page and oral feedback, where need be).

\subsection{University-administered students’ feedback survey}

As Table 2 shows, overall student satisfaction with PPE has improved in student ratings since 2014. In all areas, more students strongly agree that the subject is satisfactorily taught; and the overall SFS score has been substantially higher than in the previous three years. Qualitative responses contained in the questionnaires had comments such as "I received constructive feedback when needed”, "good feedback on assignments”, "yes the feedback helped very much so", "provided constructive feedback throughout every class", "was very good at giving written feedback which assisted in future assignment" [UTS, (2014), p.2] and "provided well-structured classes, with class debates, discussions 
and lectures. Work was explained with effective concepts and the class was operated at a high level” [UTS, (2014), pp.3-4].

Table 2 Key indicators in the students’ feedback survey (SFS) results, 2010-2016

\begin{tabular}{lcccccc}
\hline & 2010 & 2011 & 2012 & 2013 & 2014 & 2016 \\
\hline Enrolled (no.) & 59 & 52 & 57 & 57 & 51 & 92 \\
Responding (no.) & 33 & 29 & 21 & 14 & 16 & 55 \\
Response rate (\%) & 56 & 56 & 37 & 25 & 31 & 60 \\
Overall satisfaction for subject quality & 3.78 & 2.54 & 2.81 & 2.21 & 3.50 & 3.80 \\
Overall satisfaction with staff member & 3.97 & 3.69 & 3.83 & 2.57 & 3.81 & 4.25 \\
\hline
\end{tabular}

Notes: The assessment of staff member is that of the lead teacher. This is important because the teacher carries out between $85-90 \%$ of the instruction needed. In 2010, for example, there were three teachers for this subject, but each taught only about one session. Often, the lead teacher coordinates and teaches the subject and also prepares objectives and aims. I started leading the teaching of the subject in 2014 and I have typically taught the subject alone.

Source: UTS student feedback survey (SFS) various years

The scores for overall satisfaction with both quality of the subject and the quality of the faculty member's contribution have increased substantially. For example, between 2011 and 2016, the rating for the quality of the subject increased from 2.54 to 3.80. Around the same time, the rating of the contribution of faculty rose from 3.69 to 4.25 . The ratings of the subject compare favourably with the average of the Bachelor of Property Economics degree or course. In 2011, PPE ratings were 1.18 points below the property economics course. Similarly, in 2012, the PPE unit of study was rated 0.87 points below the average subject quality rating of the property economics course. In 2014, when I took over the development of the subject for the first time, PPE was again rated less favourably than the course-wide average although by a lower margin of 0.42 .

Figure 3 Overall satisfaction with quality of unit/subject, 2011-2016 (see online version for colours)

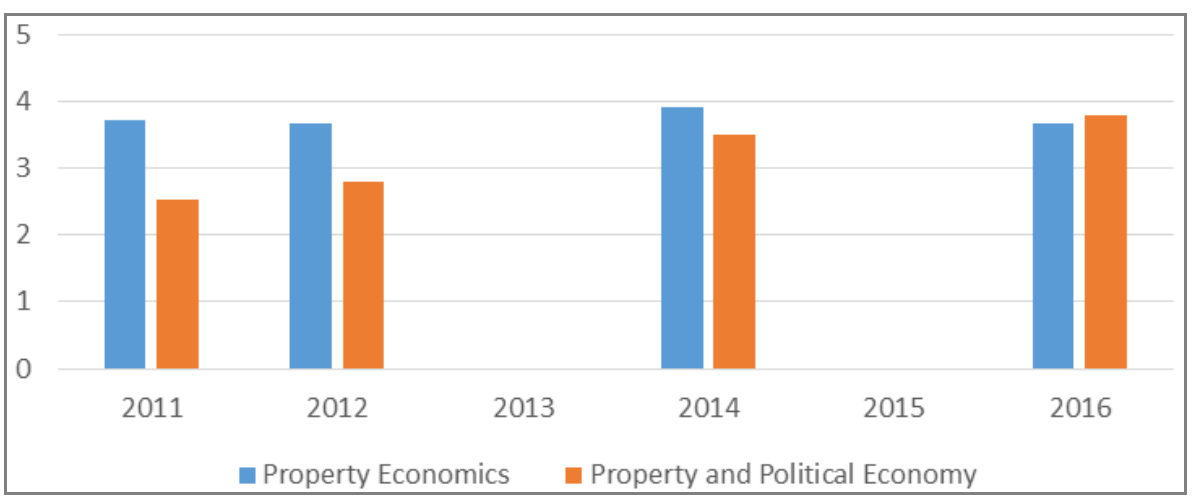

Source: UTS SFS various years 
Then, in 2016, the new PPE received better ratings. In terms of content, the overall satisfaction for PPE was 3.80 points, while that for the Bachelor of Property Economics degree or course was only 3.68. Similarly, as Figure 4 shows, the overall satisfaction with the staff member teaching the PPE unit of study has become higher than the average of the property economics course or degree programme.

Figure 4 Overall satisfaction with teacher, 2011-2016 (see online version for colours)

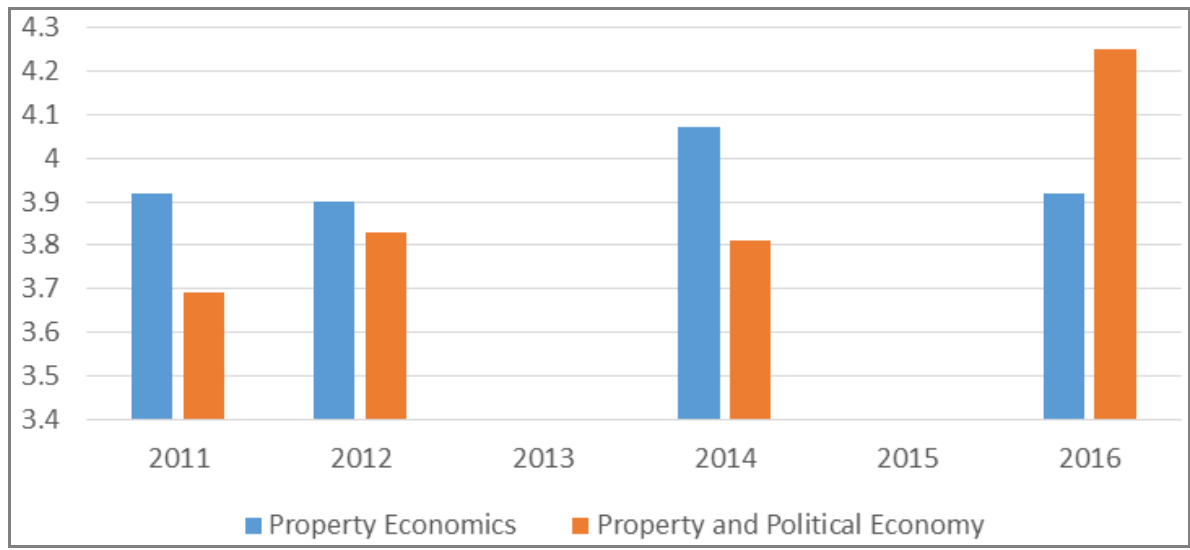

Source: UTS SFS various years

In 2016, the staff member of the new PPE unit was rated at 4.25 which was much higher than both the average overall property economics ratings in 2016 (3.92) and its five-year (2011-2016) average (3.95).

University-run students' feedback surveys, however, do not tell us everything we need to know about quality teaching. A particular concern is its inability to contextualise the feedback of students who do not consistently attend classes. Feedback from such students is valuable, of course, but it must be contextualised because in a dialogical approach to teaching, face-to-face meeting is a crucial pedagogic practice in the learning process. So, it is important to zoom in on the evaluation of students who actually attend classes and do so consistently.

\subsection{Student-administered questionnaires}

One way to capture the assessment of such students is to place the collection of feedback in the hands of students themselves in a survey that is neither pre-announced nor pre-planned. This approach has been used by some teachers at the Department of Political Economy at the University of Sydney (Stilwell, 2011). Unlike SFS models which are mainly based on the banking model of education, this model is based on a dialogical philosophy which relates student effort to teaching effort before making a judgment of the learning experience (Freire, 1970). For the survey of my class, a student volunteered to conduct the survey, collect the responses, and seal them. The responses were anonymous and I was not present. Table 3 contains the results of the surveys conducted in 2014 and 2016. 
Teaching political economy to students of property economics

Table 3 Overall satisfaction with PPE, 2014-2016

\begin{tabular}{lcc}
\hline Rating & 2014 & 2016 \\
\hline 1 (very poor) & 0 & 0 \\
2 & 1 & 1 \\
3 & 9 & 5 \\
4 & 18 & 23 \\
5 (excellent) & 7 & 10 \\
Total*responding/enrolled & $35: 51$ & $39: 92$ \\
\hline
\end{tabular}

Notes: *38 students answered the survey in 2014 , but three had to be excluded because they did not specifically answer the question on overall satisfaction. These three had provided very positive feedback on other questions such as "what is your assessment of the administration of the subject?" (q 5) and "what is your assessment of the feedback you have received from your lecturer?" (q 6).

Source: Student-administered survey, 2014

Based on the responses summarised in Table $3,71 \%$ of the students responding to the survey in 2014 regarded the subject as very good or excellent. In 2016, the share of students offering the same positive evaluation of the subject increased to $85 \%$. This evidence shows that PPE has improved its effectiveness in engaging students. However, the jury is still out whether the students are convinced of the need for pluralism in their economics education. In 2014, the survey contained the question: "what is your assessment of the subject [PPE] against the attached UTS graduate attributes for the property course” (q.7). These attributes, CAPRI, in short, are shown here in Table 4.

Developing the attributes in Table 4 is what the property economics course is supposed to do, although it is not expected that any one subject within it will achieve all the attributes. So what the students were rating was how well PPE contributes to the graduate attributes.

Table 5 summarises their responses. The students' rating for communication and interpersonal skills, for research and critical thinking; and for attitudes and values were notably positive: in the former case $73 \%$ thought the subject was either good (4) or excellent (5) and in the latter case $76 \%$ did so. However, the ratings in relation to other attributes were lower: only 53\% for 'practical and professional skills' and $61 \%$ of students rating PPE for contribution to 'innovation and creativity'.

It is possible that the relatively low ratings of the subject in terms of its contribution to 'practical and professional skills' reflected the high proportion of students who were already working as valuers, property managers, and property developers. This interpretation is grounded in the qualitative responses to question 8: "on the basis of your assessment in question 7, would you say that the study of PPE is fundamental in the education of the modern property economist?” Only eight students strongly agreed, ten other students agreed, and 13 students were undecided, one student strongly disagreed and two students disagreed. 
Table 4 Assessment of PPE against graduate attributes for UTS undergraduate property course, 2014

\begin{tabular}{|c|c|}
\hline \multicolumn{2}{|c|}{ Communication and interpersonal skills } \\
\hline $\mathrm{C} 1$ & Ability to effectively use oral communication in built environment contexts \\
\hline $\mathrm{C} 2$ & Ability to effectively communicate in writing in built environment contexts \\
\hline C3 & Ability to work effectively in a team in a built environment context \\
\hline $\mathrm{C} 4$ & Ability to effectively apply new communication technologies \\
\hline C5 & Ability to communicate complex ideas to a varied audience \\
\hline \multicolumn{2}{|c|}{ Attitudes and values } \\
\hline A1 & $\begin{array}{l}\text { Ability to identify ethical issues and make ethical judgements in built environment } \\
\text { contexts }\end{array}$ \\
\hline A2 & $\begin{array}{l}\text { Ability to manage cultural diversity and indigenous perspectives to meet stakeholders' } \\
\text { objectives }\end{array}$ \\
\hline \multicolumn{2}{|c|}{ Practical and professional skills } \\
\hline P1 & $\begin{array}{l}\text { Ability to correctly apply valuation theory and practice in the valuation of property for } \\
\text { different purposes }\end{array}$ \\
\hline P2 & Ability to make investment decisions in various contexts \\
\hline P3 & Ability to apply economic theory in analysing property markets \\
\hline $\mathrm{P} 4$ & Ability to apply planning principles in various contexts \\
\hline P5 & Ability to apply financial principles in various contexts \\
\hline P6 & Ability to apply knowledge of law and regulations in built environment contexts \\
\hline P7 & $\begin{array}{l}\text { Ability to understand sustainability and environmental issues in built environment } \\
\text { contexts }\end{array}$ \\
\hline P8 & Ability to formulate methodology for independent research projects \\
\hline \multicolumn{2}{|c|}{ Research and critical thinking } \\
\hline $\mathrm{R} 1$ & Ability to engage critical and reflective thinking in built environment contexts \\
\hline $\mathrm{R} 2$ & $\begin{array}{l}\text { Ability to source, evaluate and use information within defined parameters (research } \\
\text { application) }\end{array}$ \\
\hline R3 & Ability to analyse, structure and report the results of research (research skills) \\
\hline R4 & Ability to apply appropriate referencing in written communications \\
\hline R5 & Ability to demonstrate judgement in critical analysis of independent research \\
\hline \multicolumn{2}{|c|}{ Innovation and creativity } \\
\hline I1 & Ability to develop and formulate creative solutions to built environment issues \\
\hline $\mathrm{I} 2$ & $\begin{array}{l}\text { Ability to be adaptable to changing processes, developments, methodologies and } \\
\text { technologies inbuilt environment contexts }\end{array}$ \\
\hline
\end{tabular}

Source: UTS (2013b) code-named 'GA/UGProperty/Feb2013'

One student wrote "I don't think it is at all relevant, to be honest. I don't understand why I need to know about topics such as food crisis when I want to become a property developer”. In a formal in-class debate on whether the PPE unit of study is fundamental to the work of property economists, with students acting as judges, the 'against' team of debaters won by a unanimous decision. Their general case was that the work of a property economist is to value, develop, sell, or manage real estate or real estate funds 
and, for that purpose a pluralist subject like PPE is less fundamental. The team speaking for the motion did not show that, even in such roles, pluralist political economy could help to nudge the system away from problems such as recurrent financial crises, property-based inequality, land expropriation and food crises (see, for example, Ely, 1917, 1925; Boydell et al., 2009; Sheehan, 2012; Connolly, 2014; Gaffney, 2015; Obeng-Odoom, 2014, 2017). The 'against' team made a much simpler and stronger case. Outside the strictures of the formal debate, however, some students continue to show stronger appreciation and higher levels of enthusiasm for the study of PPE and pluralism in economics education.

Table 5 Overall rating of PPE against graduate attributes, 2014

\begin{tabular}{lccccc}
\hline Rating & $\begin{array}{c}\text { Communication } \\
\text { and interpersonal } \\
\text { skills }\end{array}$ & $\begin{array}{c}\text { Attitudes } \\
\text { and values }\end{array}$ & $\begin{array}{c}\text { Practical and } \\
\text { professional } \\
\text { skills }\end{array}$ & $\begin{array}{c}\text { Research } \\
\text { and critical } \\
\text { thinking }\end{array}$ & $\begin{array}{c}\text { Innovation } \\
\text { and } \\
\text { creativity }\end{array}$ \\
\hline 1 (very poor) & 0 & 0 & 1 & 0 & 0 \\
2 & 2 & 2 & 6 & 1 & 6 \\
3 & 7 & 6 & 8 & 8 & 6 \\
4 & 17 & 17 & 13 & 13 & 6 \\
\hline (excellent) & 7 & 8 & 4 & 11 & 6 \\
\hline
\end{tabular}

Source: Student-administered survey, 2014

\subsection{Qualitative evaluations from students: emphasis on unsolicited student feedback}

Qualitative evaluations gleaned from both university-run surveys and student-administered questionnaires have clarified what students find appealing about PPE teaching. One student noted in the open-ended section of the 2016 SFS that "[the lecturer] listened to our criticism of lecture slides and improved them which I'm very happy about". In 2014, another student noted, "I think the management of the class improved leaps and bounds over the semester, so maybe just keep it up. Nice work”.

In the student-administered questionnaires of 2016, one respondent noted that "[teacher] takes care of his students and wants the best out of their university education" (feedback for PPE 2016 student questionnaire). Another student noted, "I have never had a lecturer remember my name after an entire year. Properly, he wants us to succeed!” (feedback for PPE 2016 student questionnaire, emphasis in original). Another wrote "memorising student's names is awesome" (feedback for PPE 2016 student questionnaire). A third observed that "[teacher] replies within a few hours to every e-mail I have sent him" (feedback for PPE 2014 student questionnaire). These comments confirm that being interested in the personal experiences and needs of students is important in shaping their perceptions of quality. Indeed, it is probably reasonable to infer from the experience and evidence that these pedagogical features were more highly valued and influential on learning outcomes than the pluralist character of the curriculum.

Some students could recognise connections between subject matter and teaching practices, though. As one student put it "very interesting topics, which provides a snapshot of the greater effects the construction industry has on the world. Also, [teacher's] enthusiasm and passion for teaching is very motivating” (feedback for PPE 
2016 student questionnaire). Another noted, "interactive and interesting way of learning content + hearing different opinions” (feedback for PPE 2014 student questionnaire).

Subsequent unsolicited student feedback has also confirmed the positive evaluation of PPE. One student identified the importance of the subject in developing students' ability to think for themselves, writing, “you've really expanded and challenged my perspective on how to analyse the world. I've only really been taught what to think, not how to think, so I really appreciate all the comments on my essay - I always welcome constructive criticism!” (female student, e-mail sent to me on 11 September 2014, emphasis in original). Another identified a distinctive political economy strength of pluralism and its inherent democratic character of persuasion over indoctrination and open-ness over tunnel-vision, writing that "you have opened my eyes to the expansive world of economics. I, like you, hope to impact people's perception of current economic systems. I hope you find this book interesting and informative. Thanks for being the most outstanding, personable lecturer" (male student, a statement handwritten in a book by Naomi Klein - This Changes Everything - which the student gave me after the end of our meetings in 2014). A third student stressed that, unlike other units of study in the property economics course, PPE is educational; not vocational, committed to education rather than training, and having analytical/ethical foundations. In her own words: "You've shown me how important property is in our economy but more importantly how economic theory can impact a nation. I once believed the capitalist way was the only way, but since taking your classes I've started to question if sometimes the capitalist way compromise morals and if the costs out way [sic] the benefits" (female student's response to an e-mail from me asking whether she will be studying more, 16th January 2017).

\section{Conclusions}

So, is teaching pluralist political economy to property economics students mission impossible? The experience in teaching PPE within a mainstream property economics degree or programme at the University of Technology Sydney shows that pluralism in economics education can flourish even in a mainstream property economics programme. This finding is consistent with the experience of the political economy teaching within the former Faculty of Economics at the University of Sydney (see Butler et al., 2009; Stilwell, 2006, 2011, 2012), where political economy electives were well received by students, including those enrolled in mainstream economics course. In other words, the evidence against the self-selection thesis is quite strong: if given the opportunity, and well-taught, student enthusiasm for a pluralist and potentially more challenging and radical alternative can be nurtured, and can change students' understandings and outlooks.

The patterns of success of political economy subjects are better explained by social provisioning rather than self-selection. However, merely putting the case for pluralism is unlikely to enhance students' interest, especially for those students at my own university who, unlike the students at the University of Sydney, are not enrolled in a comprehensive political economy program. However, as this article has shown, even in a more conservative vocationally-oriented educational context, the case for pluralism can be more effectively put, if it is complemented with pedagogic revisions. The latter include 
1 reorienting the content of the subject towards real world issues, directly challenging what students know, and offering alternatives for social change

2 making the teaching methods dialogical

3 establishing closer alignment between aims, assessment, and teaching processes which, as I have shown, enhance student interest.

There is clearly more room for improvement and greater need for additional studies to ascertain how the skills developed by students who have experienced pluralism in their studies percolate the output of property economists in the workforce. Also pertinent is studying the experiences of former students who now work in broader fields of property economics, such as urban economic development and international land policy, to ascertain how PPE has helped in their role - and using that information to develop ways of making PPE a better unit of study. Such future investigative studies can identify ways to create, maintain, and develop property economists who have been exposed to pluralism in economics education and are willing to confront the property-based structures of capitalism that they studied at university.

\section{Acknowledgements}

I acknowledge feedback from, in particular, Dr. Jack Reardon (Editor-in-Chief of this journal) and two reviewers of International Journal of Pluralism and Economics Education whose detailed constructive criticism has helped to improve the quality of the paper. Many thanks to Prof. (retired) Spike Boydell, Prof. John Sheehan, Associate Prof. Garrick Small, and Dr. Mike McDermott who have been very supportive in developing my teaching and PPE generally. Dr. Jenny Pizzica offered me very helpful feedback on course design and assessment for which I am very grateful. The students, teachers, colleagues, and other teachers who offered me suggestions for developing PPE deserve many thanks. Prof. Emeritus Frank Stilwell deserves my special thanks for his usual helpful and detailed feedback on developing this paper and, more fundamentally, for his unswerving support of my teaching and research in political economy in the last decade.

\section{References}

Biggs, J.B. and Tang, C. (2011) Teaching for Quality Learning at University, 4th ed., McGraw Hill Education \& Open University Press, Maidenhead.

Boyd, S. (2016) 'Experiencing university through property', Pacific Rim Property Research Journal, Vol. 22, No. 1, pp.31-44.

Boud, D. and Falchikov, N. (Eds.) (2007) Rethinking Assessment in Higher Education: Learning for the Longer Term, Routledge, London.

Boydell, S. (2007) 'Disillusion, dilemma and direction: the role of the university in property research’, Pacific Rim Property Research Journal, Vol. 13, No. 2, pp.146161.

Boydell, S., Sheehan, J. and Prior. J. (2009) 'Commentary: Carbon property rights in context', Environmental Practice, Vol. 11, No. 2, pp.105-114.

Butler, G., Jones, E. and Stilwell, F. (2009) Political Economy Now: The Struggle for Alternative Economics at the University of Sydney, Sydney University Press, Australia. 
Connolly, N.D.B. (2014) A World More Concrete: Real Estate and the Remaking of Jim Crow South Florida, The University of Chicago Press, Chicago.

Ely, R.T. (1914) Property and Contract in their Relations to The Distribution of Wealth, Macmillan and Co., London.

Ely, R.T. (1917) 'Land property as an economic concept and as a field of research', The American Economic Review, Vol. 7, No. 1, pp.18-33.

Ely, R.T. (1925) 'Research in land and public utility economics', The Journal of Land and Public Utility Economics, Vol. 1, No. 1, pp.1-6.

Ely, R.T. (1938/2011) Ground Under Our Feet - an Autobiography, Reed Books Ltd., London.

Faculty of Design, Architecture and Building (DAB) (2017) Undergraduate Courses Guide, DAB, UTS, Sydney.

Frank, R.H., Gilovich, T. and Regan, D.T. (1993) 'Does studying economics inhibit cooperation?', The Journal of Economic Perspectives, Vol. 7, No. 2, pp.159-171.

Frank, R.H., Gilovich, T.D. and Regan, D.T. (1996) 'Do economists make bad citizens?', Journal of Economic Perspectives, Vol. 10, No. 1, pp.187-192.

Freire, P. (1970) Pedagogy of the Oppressed, Bloomsbury, New York.

Frey, B.S. and Meier, S. (2003) 'Are political economists selfish and indoctrinated? Evidence from a natura l experiment', Economic Inquiry, Vol. 4, No. 3, pp.448-462.

Gaffney, M. (2015) ‘A real-assets model of economic crises: will China crash in 2015?’, American Journal of Economics and Sociology, Vol. 74, No. 2, pp.325-360.

Jayantha, W.M. and Chiang, Y.H. (2012) 'Key elements of successful graduate real estate education in Hong Kong: students' perspective', Journal of Real Estate Practice and Education, Vol. 15, No. 2, pp.101-128.

Obeng-Odoom, F. (2014) Oiling the Urban Economy: Land, Labour, Capital, and the State in Sekondi-Takoradi, Routledge, London.

Obeng-Odoom, F. (2016) Reconstructing Urban Economics: Towards a Political Economy of the Built Environment, Zed, London.

Obeng-Odoom, F. (2017) 'Unequal access to land and the current migration crisis', Land Use Policy, Vol. 62, pp.159-171.

Samuelson, P. (1938) 'A note on the pure theory of consumers behaviour', Economica, Vol. 5, No. 17, pp.61-71.

Schneider, G. (2013) 'Student evaluations, grade inflation and pluralistic teaching: moving from customer satisfaction to student learning and critical thinking', Forum for Social Economics, Vol. 42, No. 1, pp.122-135

Schulte, K-W. (2002) Real Estate Education Throughout the World: Past, Present and Future, Kluwer Academic Publishers, Boston, Dordrecht, London.

Sheehan, J. (2012) ‘Applying an Australian native title framework to Bedouin property', in Amara, A., Abu-Saad, I. and Yiftachel, O. (Eds.): Indigenous Justice: Human Rights Law and Bedouin Arabs in the Naqab/Negev, pp.228-253, Harvard University Press, Cambridge.

Small, G. (2001) 'Property theory: what is it and why teach it', Presented at the 2001 Pacific Rim Real Estate Society Conference, Adelaide, Australia.

Stilwell, F. (2005) 'Teaching political economy: curriculum and pedagogy', Proceedings of the Eleventh Australasian Teaching Economics Conference: Innovation for Student Engagement in Economics, Sydney University, pp.107-118.

Stilwell, F. (2006) 'The struggle for political economy at the University of Sydney', Review of Radical Political Economics, Vol. 38, No. 4, pp.539-550.

Stilwell, F. (2011) 'Teaching a pluralist course in economics: the University of Sydney experience', International Journal of Pluralism and Economics Education, Vol. 2, No. 1, pp.39-56.

Stilwell, F. (2012) 'Teaching political economy: making a difference?’, Studies in Political Economy: a Socialist Review, Vol. 89, No. 1, pp.147-163. 
Thornton, T. (2014) 'A conversation with Emeritus professor Frank Stilwell', International Journal of Pluralism and Economics Education, Vol. 5, No. 2, pp.113-119.

Thornton, T. (2015) 'The changing face of mainstream economics?', Journal of Australian Political Economy, Winter, Vol. 75, pp.11-26.

Thornton, T. (2017) From Economics to Political Economy: The Promise, Problems and Solutions of Pluralist Economics, Routledge, London.

UTS (2010) Student Feedback Results: Property and Political Economy, UTS, Sydney.

UTS (2011) Student Feedback Results: Property and Political Economy, UTS, Sydney.

UTS (2012) Student Feedback Results: Property and Political Economy, UTS, Sydney.

UTS (2013a) Student Feedback Results: Property and Political Economy, UTS, Sydney.

UTS (2013b) ‘GA/UG Property/Feb2013’ School of Built Environment, UTS, Sydney.

UTS (2014) Student Feedback Results: Property and Political Economy, UTS, Sydney.

UTS (2016) Student Feedback Results: Property and Political Economy, UTS, Sydney.

Weinstein, M. and Worzala, E. (2008) 'Graduate real estate programs: an analysis of the past and present and trends for the future', Journal of Real Estate Literature, Vol. 16, No. 3, pp.387-413.

\section{Notes}

1 Personal communication with Associate Prof. Garrick Small on 26 February 2017.

2 Ibid. 